\title{
UDC 528.18:629.783
}

\author{
B. B. PALIANYTSIA ${ }^{1 *}$, B. V. KLADOCHNYI ${ }^{1}$, O. B. PALIANYTSIA ${ }^{2}$ \\ ${ }^{1}$ Department of «Higher geodesy and astronomy» of Lviv Polytechnic National University, 12 Bandera street, Lviv, Ukraine, \\ 79013, e-mail bohdan.b.palianytsia@1pnu.ua,bodya1379@gmail.com \\ ${ }^{2}$ Department of Computational Mathematics, Ivan Franko Lviv National University, 1, Universytetska St., Lviv, Ukraine, 79000, \\ e-mail oksana.palianytsia@Inu.edu.ua
}

https://doi.org/

\section{THE RESEARCH OF SHORT-PERIODIC COMPONENTS CHANGES OF ZENITH THROPOSPHERE DELAY}

The aim of this work is the research of the magnitude of the components change of the zenith tropospheric delay for the territory of Ukraine according to several-day terrestrial meteorological measurements, as well as the construction and study of the field of their change. Method. The accuracy of the determination of the tropospheric delay and its components depends on the amount of meteorological data that can be used for its caclulation. It would be more better if, at the time of the GNSS measurements, the atmospheric sensing data were obtained near the observation point, otherwise it is necessary to simulate the meteorological situation at the time of the measurements using the data available for that purpose. The fulfilled researches evaluated the meteorological situation as a whole for the territory of Ukraine. The tropospheric delay was calculated using the well-known Saastamoenen formula. The range of change of tropospheric delay for the territory of Ukraine was subsequently created. Results. The results of the research make it possible to analyze the dependence of the change in the magnitude of the components of the tropospheric delay on the change in meteorological values in the territory of the country. The graphs of changes in tropospheric delay components during three days with the discreteness of 6 hours at four points with different climatic conditions were obtained and analyzed in the work. It has been established that despite the significant difference in the values of the components, the amplitudes of their change are close to each other: the differences of these amplitudes are $6 \mathrm{~mm}$ for the dry component and $2 \mathrm{~mm}$ for the wet component. The dynamics of change of dry (hydrostatic) and wet (non-hydrostatic) components during two days have been shown in the work. It has been noted that their dynamics are due to the change of atmospheric pressure for the dry component and the change of water vapour pressure in the troposphere for the wet component. Scientific novelty and practical significance lie in the revealed stability of the amplitude of change of components at the points located in different climatic and weather conditions. Also, it has been confirmed that the dynamics of change in the dry component is due to changes in atmospheric pressure, and wet - due to changes in partial pressure. The performed researches can be used to create regional models of the atmosphere and further studies of the field of change of the zenith tropospheric delay, as they relate to the change of the delay in space and time.

Key words: tropospheric delay; the impact of the troposphere on satellite measurements; methods for determining tropospheric delay; determination of components of tropospheric delay; GNSS measurements.

\section{Introduction}

The tropospheric delay is known to be one of the most significant factors that impair the results of GNSS measurements. The research of the methods of determining and considering this factor is an urgent task in an era of rapid development and widespread use of the satellite navigation systems. At the same time, the problem of increasing the accuracy of GNSS measurements becomes more and more urgent, which actualizes the issue of taking into account the influence of the troposphere on the results of these measurements.
Scientists from different countries, including [Askne. et al., 1987; Baby, et al., 1988; Ifadis, et. al., 2006; Mendes, 1999], as well as in Ukraine are actively engaged in research of tropospheric delay problem. In recent years, there has been an increase in publications on the subject at the Department of Higher Geodesy and Astronomy at Lviv Polytechnic National University. In some scientific works the research of methods of determination of tropospheric value delay of the signal spreading from the GCC to the receiver located at the observation point has been 
conducted, [Kablak, 2013; Pazyak, \& Zablotskyi, 2015, 2018; Turchyn, 2015; Palyanitsa, et al., 2016; Hoptar, 2017] and in others - the amount of water vapour in the troposphere of the Earth has been investigated [Zablotskyi, et. al., 2017; Paziak, 2019].

\section{Aim}

The purpose of this work is to investigate the magnitude of the change in the zenith tropospheric delay and its components for the territory of Ukraine according to several-day terrestrial meteorological measurements, as well as to construct and study the field of change of its components.

\section{Output data}

The archival data have been taken as the initial values for the research provided by the Internet resource [Raspisaniye Pogodi Ltd.], namely, surface meteorological measurements: air temperature, atmospheric pressure and relative humidity, conducted at meteorological stations and at the airports during October 2018. This provided the appropriate density of the points and the uniformity of their location throughout the country. The result is the network of points approximately evenly spaced throughout the country. The distance between the points varies between $60-240 \mathrm{~km}$.

\section{Research methodology}

The accuracy of the determination of the tropospheric delay depends directly on the amount of meteorological data that can be used to calculate it. It would be more better if, at the time of the GNSS measurements, the aerological sensing data of the atmosphere were obtained near the observation point. But, since such an opportunity is not available, it is necessary to model in some way the meteorological situation at the time of measurements, using the data available for this purpose. In the conducted investigations an attempt had been made to assess the meteorological situation as a whole for the territory of Ukraine and to plot functions of their changes for the given territory by calculating the values of the tropospheric delay and its components.

The tropospheric delay is traditionally regarded as the sum of the dry (hydrostatic) and wet (nonhydrostatic) components:

$$
d_{\text {trop }}^{z}=d_{h}^{z}+d_{w}^{z}
$$

For different values of the zenithal distance, the tropospheric delay can be calculated by multiplying the zenithal values of the delay components by the corresponding $\mathrm{m}(Z)$ mapping functions. Then the formula (1) takes the following form:

$$
d_{\text {trop }}^{z}=d_{h}^{z} \cdot m_{h}(Z)+d_{w}^{z} \cdot m_{w}(Z),
$$

where: $d_{h}{ }^{z}$ i $d_{w}{ }^{z}$ - hydrostatic (dry) and nonhydrostatic (wet) components of the antiaircraft tropospheric delay, $\mathrm{m}_{\mathrm{h}}(\mathrm{Z})$ and $\mathrm{m}_{\mathrm{w}}(\mathrm{Z})$ are the functions of displaying the dry and wet components, respectively.

The components of the tropospheric delay are calculated by integral formulas according to the aerological sensing of the atmosphere, or by analytical formulas. In this work, the terrestrial values of the meteorological magnitude were used, so the calculations were performed using analytical formulas, in particular the Saastamoenen formulas [Saastamoinen, 1972], which give reliable results of the values of the antiaircraft tropospheric delay for our region.

The Saastamoenen formula for the dry component of the zenithal troposphere has the following form:

$$
d_{h S A}=\frac{0.002277 \cdot P_{s}}{\left(1-0.0026 \cos 2 \varphi-28 \cdot 10^{-8} H_{S}\right)},
$$

and for wet - the following:

$$
d_{w S A}=0.002277 \cdot\left(\frac{1255}{T_{s}}+0.05\right) \cdot e_{0}
$$

In the formulas (3) and (4): $\varphi i H_{s}-$ the latitude and altitude of the observation station; $T_{s}, P_{s}, e_{0}-$ 
the terrestrial values of air temperature, atmospheric and partial pressure, respectively.

\section{Results of research}

In the beginning, we took the terrestrial values of meteorological magnitudes at the observation points of Lviv, Kyiv, Luhansk and Odesa, obtained in autumn, during three days with an interval of 6 hours. It should be noted that each of the points is located in a different climate zone with specific features: Lviv is near the Carpathian Mountains, Kyiv - in the more continental zone, Lugansk - in the steppe zone, and Odesa - on the seashore. According to the obtained values, the graphs of changes in the components of the tropospheric delay were plotted.

The graphs show us that at the selected observation points during the specified period there is an increase in the dry component. At the observation points of Lviv and Odesa, the value of the delay increased evenly, and at the point of Luhansk, a sudden increase on the second day of observation was noticed. At the point of Kyiv, there was an uneven increase in the component with a rapid abatement in the first half of the second day.

The dry component varied within $15 \mathrm{~mm}$, which is $0.6 \%$ compared to the average component of $2300 \mathrm{~mm}$ and is considered as a slight change.

The wet component is more variable and difficult to predict. When considering its change

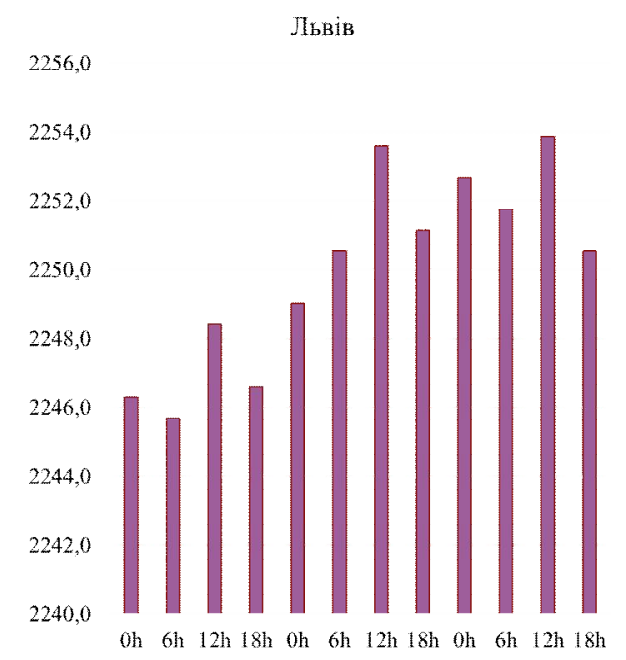

during the day, you can see that it takes the largest values in the afternoon and decreases in the night and in the morning. The maximum growth of the component is more than $40 \mathrm{~mm}$ and is noticeable in the afternoon when the daily air temperature is the highest. This is explained by the fact that despite the inverse proportion between the air temperature and the wet component (this can be seen in formula 4), the change in the partial pressure caused by the change in temperature significantly influences the value of the component, changing it in the other direction. The wet component varied within $50 \mathrm{~mm}$, which is palpable and, in some cases, almost $50 \%$ of the wet component, when we take into account the average component value of about $100 \mathrm{~mm}$.

The magnitudes of the component changes at selected points are shown in Tables 1 and 2. It can be seen that, despite the significant differences in the values of the corrections, the amplitudes of their changes are quite close in value, and for the wet component, they are almost equal.

And therefore, as in [Kladochny, \& Palyanytsya, 2018], according to the data selected for each regional centre of Ukraine, the fields of dry and wet components of tropospheric delay were constructed, and, for comparison, as well as the fields of atmospheric and partial pressure.

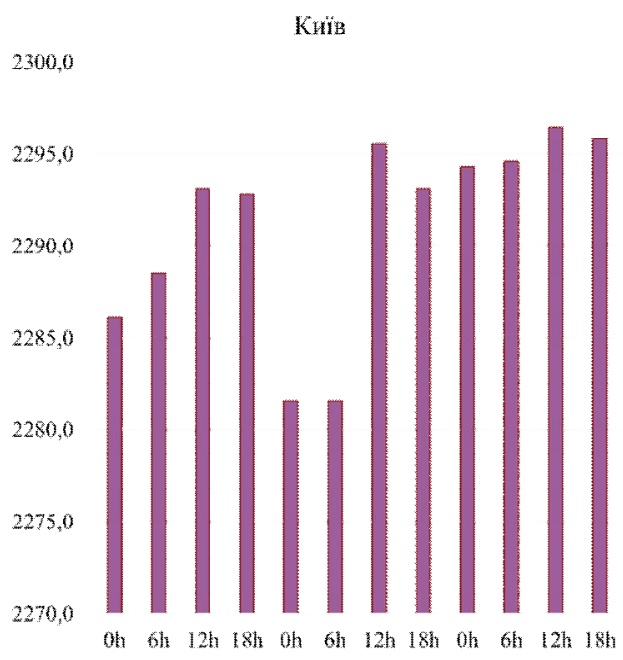

Fig. 1, 2. Change of the dry component delay during three days at the points of Lviv and Kyiv 


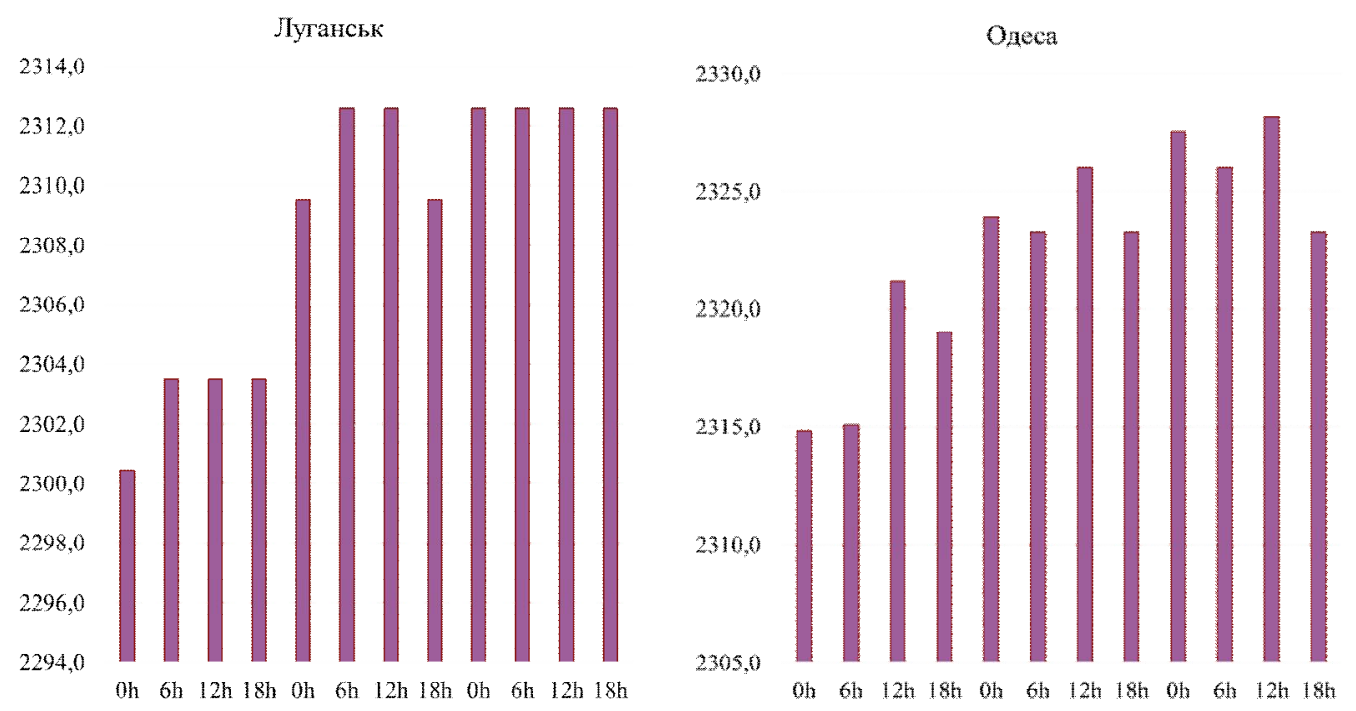

Fig. 3, 4. Change of dry component delay during three days at the points of Luhansk and Odesa
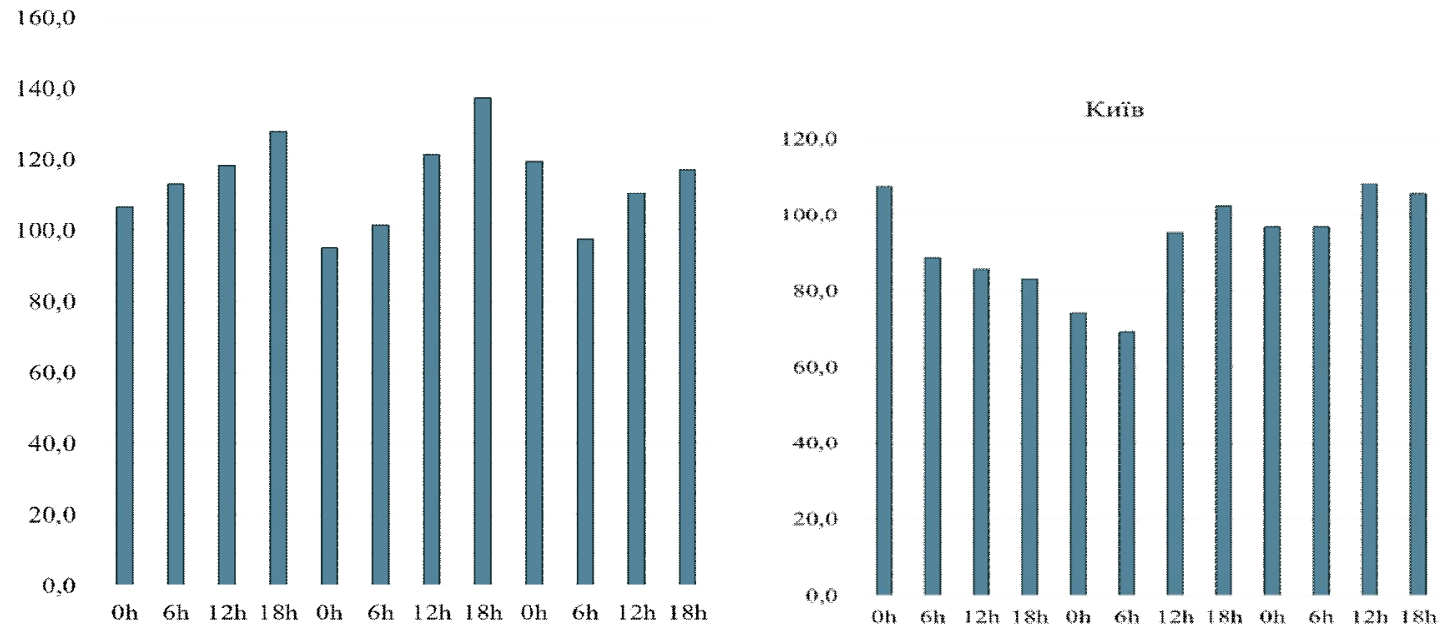

Fig. 5, 6. Change of wet component of delay during three days at the points of Lviv and Kyiv

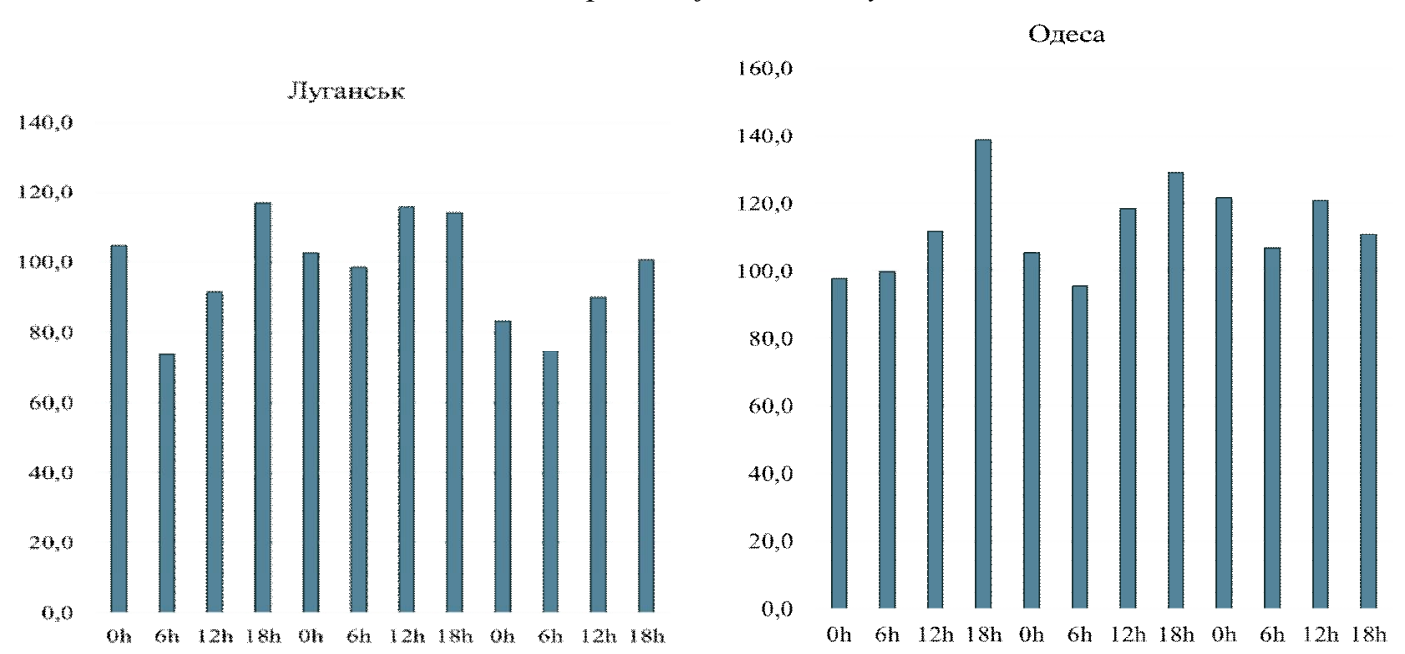

Fig. 7, 8. Change of wet component of delay during three days at the points of Luhansk and Odesa 
Table 1 October 11, 2018. The figures below show the

\begin{tabular}{|c|c|c|c|}
\hline \multirow{2}{*}{$\begin{array}{c}\text { The name } \\
\text { of the point }\end{array}$} & \multicolumn{3}{|c|}{ The value of dry component, mm } \\
\cline { 2 - 4 } & Max. & Min. & Differences \\
\hline Lviv & 2254 & 2246 & 8 \\
\hline Kyiv & 2295 & 2281 & 14 \\
\hline Luhansk & 2313 & 2300 & 13 \\
\hline Odesa & 2327 & 2315 & 12 \\
\hline
\end{tabular}
dynamics of the change of the atmospheric pressure and the dry component of the tropospheric delay. It can be seen that the dry component repeats the changes of the atmospheric pressure, but changes more dynamically. In Fig. 9-12 it is observed more to

Table 2

\begin{tabular}{|c|c|c|c|}
\hline \multirow{2}{*}{$\begin{array}{c}\text { The name } \\
\text { of the point }\end{array}$} & \multicolumn{3}{|c|}{ The value of wet component, mm } \\
\cline { 2 - 4 } & Max. & Min. & Differences \\
\hline Lviv & 140 & 96 & 44 \\
\hline Kyiv & 110 & 64 & 46 \\
\hline Luhansk & 119 & 73 & 46 \\
\hline Odesa & 140 & 97 & 44 \\
\hline
\end{tabular}
the west of Kharkiv and to the east of Lviv. Concerning the wet component, it changes much faster than the dry component and correlates with the change of partial pressure.

In the figures below, the correlation of the dry

In order to illustrate the dynamics of components and the meteorological values that have the greatest effect on their changes, the figures 9-20 showed images taken at 12-hour intervals, that is, at 12 o'clock on October 10 , and at 00 o'clock and 12 o'clock in Kyiv time on and wet components of the tropospheric delay with the values of atmospheric and partial pressure is obvious. Also, according to the data used for the calculations, there is a regularity that the dry component is higher in the central part of Ukraine, and the wet component - in the southern and the western part of the country.

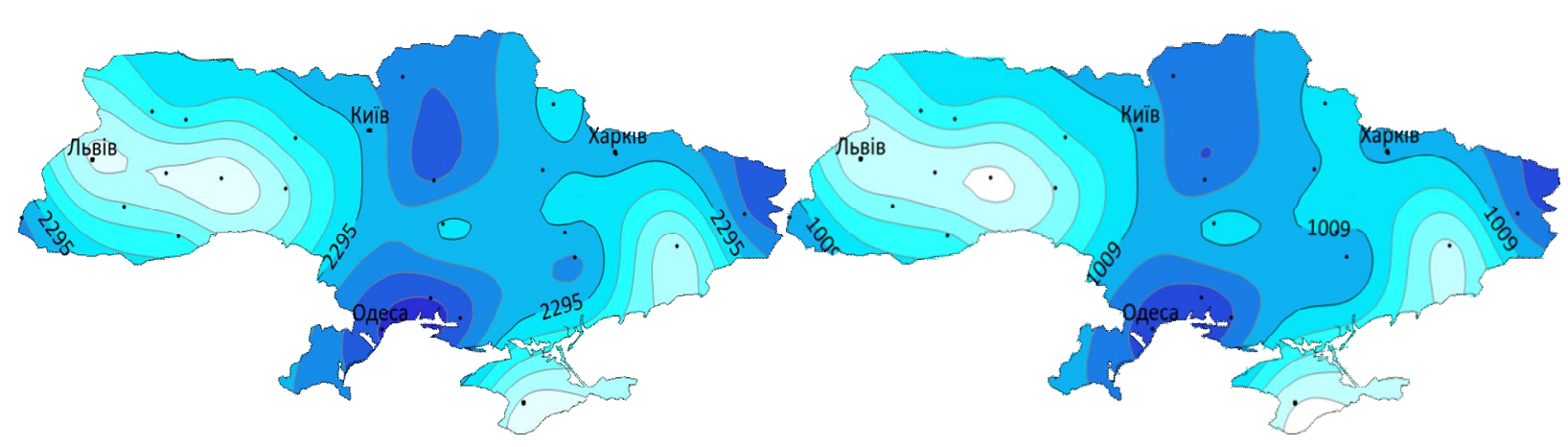

Fig. 9, 10. Atmospheric pressure field (left in GPa) and dry component (right in $\mathrm{mm}$ ) at 12 o'clock on October 10
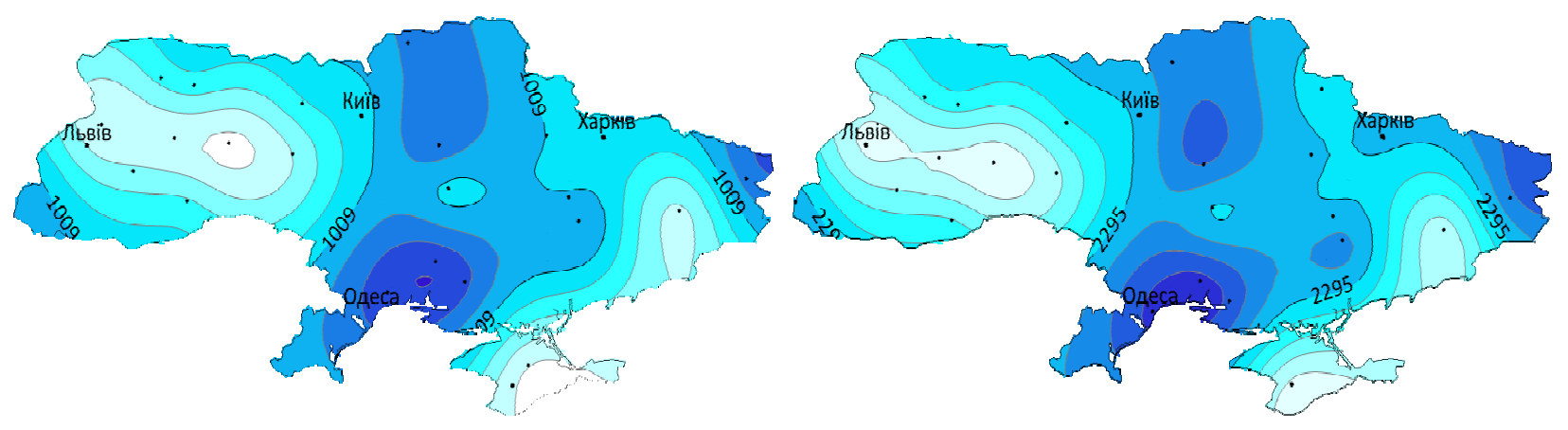

Fig. 11, 12. Atmospheric pressure field (left) and dry component (right) at 00 o'clock on October 11 


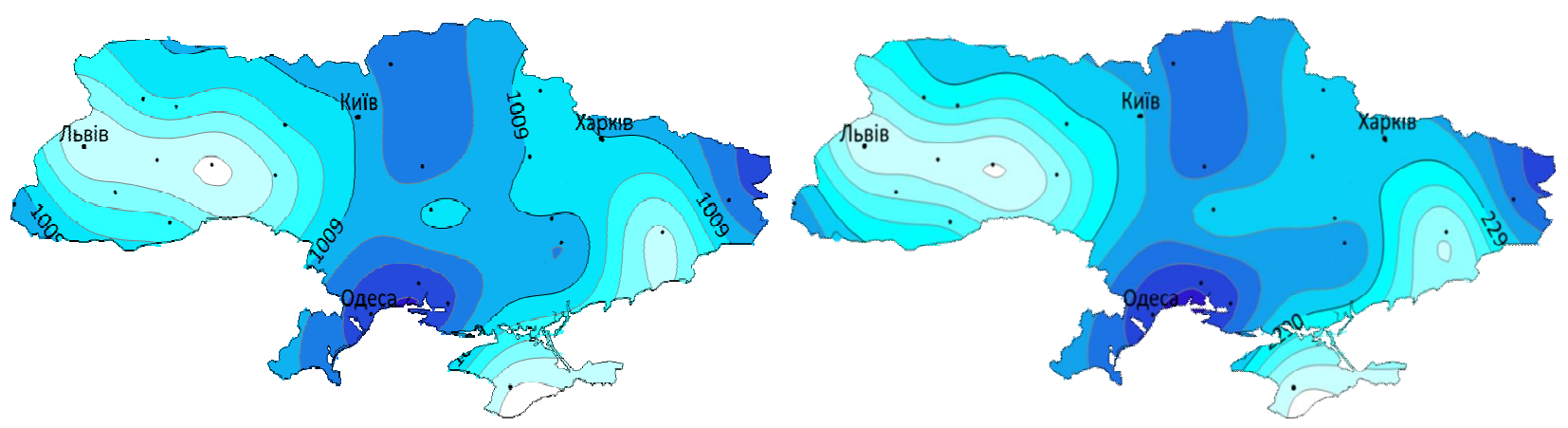

Fig. 13, 14. Atmospheric pressure field (left) and dry component (right) at 12 o'clock on October 11
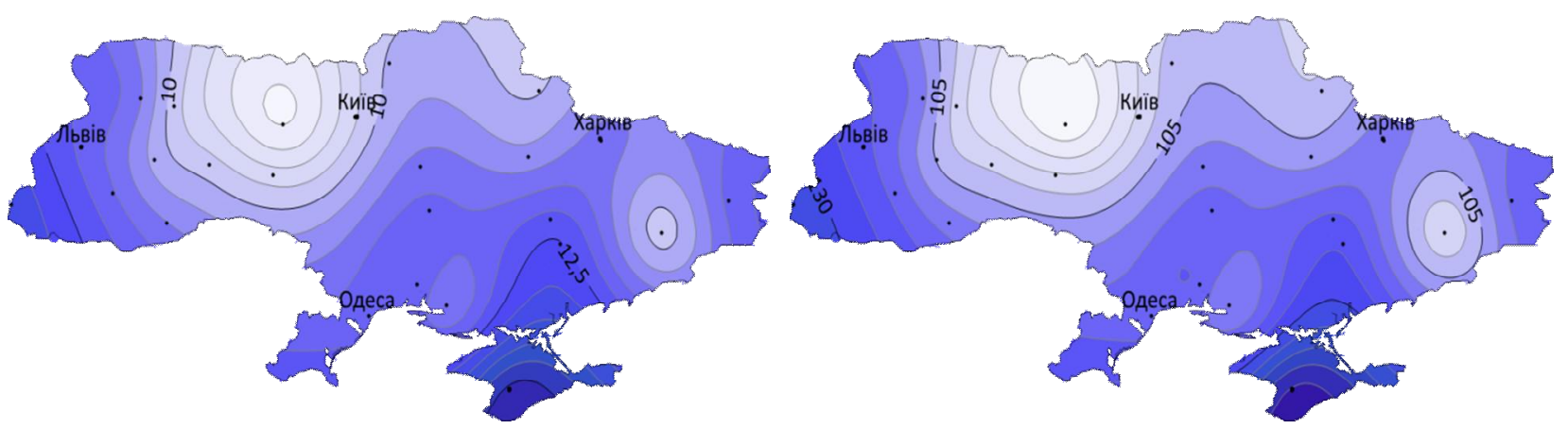

Fig. 15, 16. Field of partial pressure (left) and wet component (right) at $12 \mathrm{o}^{\prime}$ clock on October 10
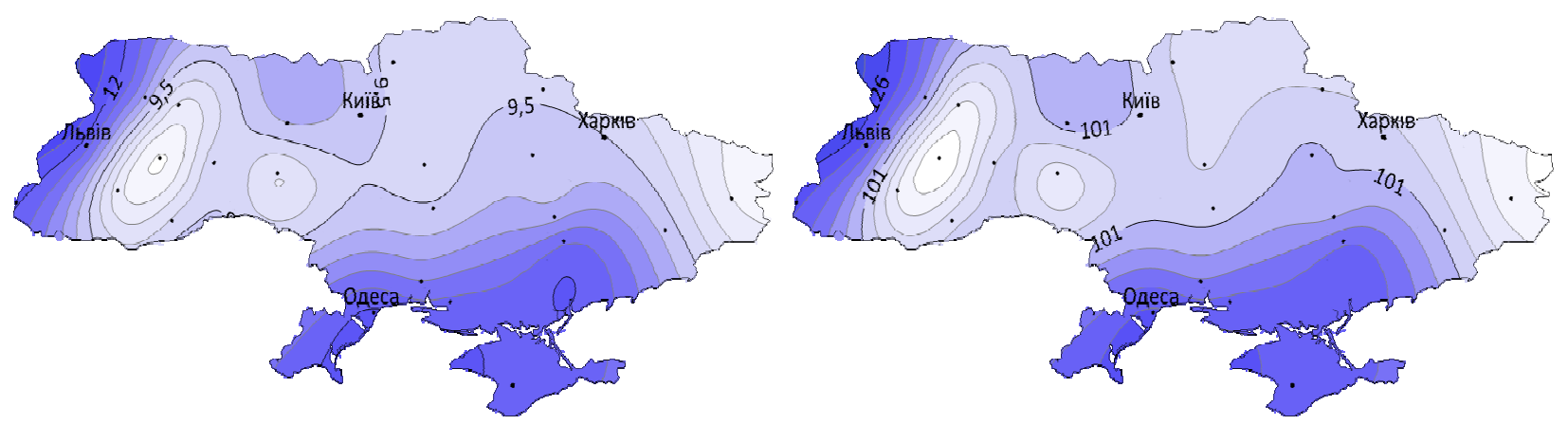

Fig. 17, 18. Field of partial pressure (left) and wet component (right) at $00 o^{\prime}$ clock on October 11
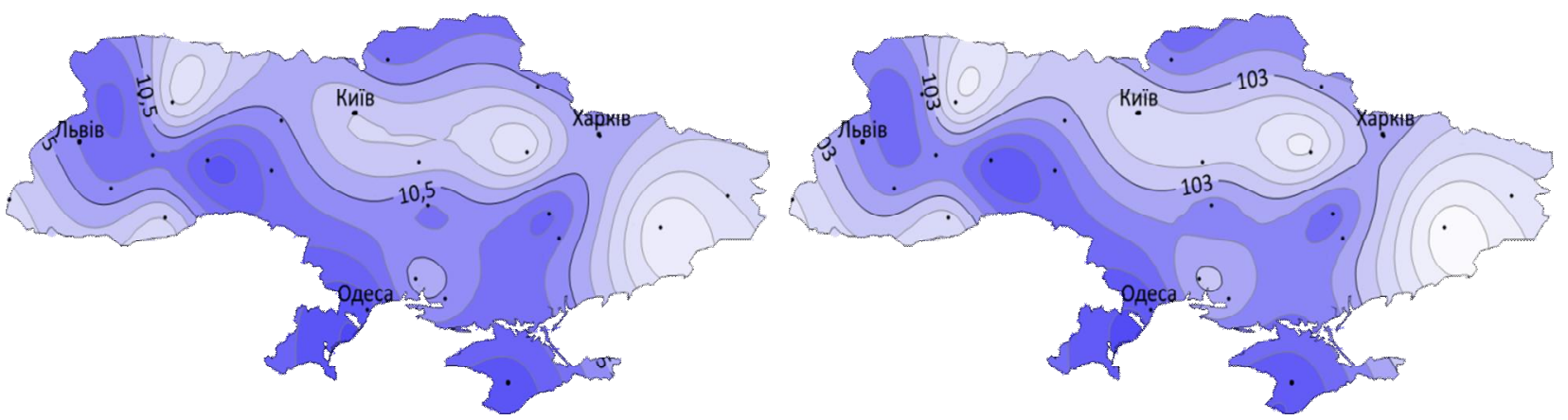

Fig. 19, 20. Field of partial pressure (left) and wet component (right) at $12 o^{\prime}$ clock on October 11 
As we can see from the figures above, the dynamics of the change in the dry component are negligible, as well as of the atmospheric pressure, despite the fact that one of the moments in time is in the night period. Concerning the wet component, the dynamics of its change are larger, though on a much smaller scale, and this change was different in different parts of the territory of Ukraine.

\section{Scientific novelty and practical significance}

The scientific novelty of the research lies in the revealed stability of the amplitude of change of components at the observation points in different climatic and weather conditions. Also, it was confirmed that the dynamics of change in the dry component are due to changes in atmospheric pressure, and wet - due to changes in partial pressure.

The results can be used to create regional models of the atmosphere and for further investigation of the range of change of zenith tropospheric delay, as they relate to changes of delay in space and time.

\section{Conclusions}

Considering the distribution of delay values in the territory of Ukraine for the indicated three-day period, it can be mentioned that the dry component becomes more important in the southern and central part of the territory of Ukraine.

During this period, the humidity component was higher in southern Ukraine, where relative humidity was higher, and also in western Ukraine, due to weather and higher humidity. It is difficult to predict it because it depends on air temperature and humidity, which differently affect the magnitude of this component.

It has been established that despite the significant difference in the values of the components, the amplitudes of their change are close to each other: the differences of these amplitudes are $6 \mathrm{~mm}$ for the dry component and $2 \mathrm{~mm}$ for the wet component.

The dynamics of the change of the dry component are smaller in this period than the wet component and is largely due to changes in atmospheric pressure, and the change in the wet component is due to changes in water vapour pressure in the Earth's troposphere.

\section{REFERENCES}

Askne, J., \& Nordius, H. (1987). Estimation of tropospheric delay for microwaves from surfaces weather data. Radio Sciense, 22(3). 379-386.

Baby, H. B., Gole, P., \& Lavergnal, J. (1988). A model for the tropospheric excess path length of radio waves from surface meteorological measurements. Radio Sciense. 23(6). 1023-1038.

Ifadis, I. M., Katsoungiannopoulos, S., Pikridas, C., Rossikopoulos, D., \& Fotiou, A. (2006). Tropospheric Refraction Estimation Using Various Models, Radio-sonde Measurements and Permanent GPS Data. PS5.4 - GNSS Processing and Applications, XXIII FIG Congress, Munich, Germany, October 8-13, 2006. P. 15.

Kablak, N. (2013). Method of determinating the influence of results troposphere GNSS-measurements in a network of active reference stations. Modern achievements in geodetic science and industry, I(25). 62-66.

Khoptar, A. (2017). Method of determining of tropospheric parameters from compatible data of SLR and GNSS observations. Modern achievements in geodetic science and industry, II(34). 51-54.

Kladochnyi, B., \& Palianytsia, B. (2018). The research of change in the components of zenith tropospheric delay. International scientific and technical conference GeoTerrace-2018. Lviv, Ukraine, 13 - 15 december 2018, 21-24.

Mendes, V. B. (1999). Modeling the neutralatmosphere propagation delay in radiometric space techniques. Ph.D. dissertation, Department of Geodesy and Geomatics Engineering Technical Report No. 199, University of New Brunwick, Fredericton, New Brunswick, Canada. 
Palianytsia, B., Oliynyk, V., \& Boyko, V. (2016). The research of change of zenith troposperic dealay's components. Geodesy, Cartography and Aerial Photography, 83, 13-20.

Paziak, M., \& Zablotskyi, F. (2018). Features of the vertical destributions of the wet component of zenith tropospheric delay in middle and tropical latitudes. Modern achievements in geodetic science and industry, 2018. II(36). 41-49.

Paziak, M., \& Zablotskyi, F. (2015). Comparison of wet component of zenith tropospheric delay derived from GNSS observations with correspondding value from radio soundings. Geodesy, Cartography and Aerial Photography, 81, 16-24.

Paziak, M., (2019). Determination of precipitable water vapour, from the data of aerological ang GNSS measurements at europpean and tropical stations. Geodesy, Cartography and Aerial Photography, 89, 20-28.
Turchin, N. \& Zablotskyi, F (2015). Modern approaches to determining troposphere delays and its components. Geodesy, cartogrphy and aerial photography. 78. 155-159.

Raspisaniye Pogodi Ltd., St. Petersburg, Russia, internet resource: rp5.ua.

Saastamoinen, J. (1972). Atmospheric correction for the troposphere and stratosphere in radio ranging of satellites. The Use of Artifical Satellites for Geodesy, Geophysics. Monogr. Ser., Vol. 15, AGU, Washington, D.C., P. 247251 .

Zablotskyi, F.,.Gresko, Ju, \& Palanytsa, B. (2017). Monitoring of water vapour content by radio sounding data at the Kyiv aerological station and by GNSS observation data at the GLSV station. Geodesy, Cartography and Aerial Photography, 85, 13-17.

\footnotetext{
Б. Б. ПАЛЯНИЦЯ ${ }^{1 *}$, Б. В. КЛАДОЧНИЙ ${ }^{1}$, О. Б. ПАЛЯНИЦЯ ${ }^{2}$

${ }^{1}$ Кафедра вищої геодезії та астрономії, Національний університет «Львівська політехніка», вул. С. Бандери 12 , Львів, Україна, 79013, ел. пошта bohdan.b.palianytsia@lpnu.ua, bodya1379@gmail.com

2 Кафедра обчислювальної математики, Львівський національний університет ім. Івана Франка, вул. Університетська 1, Львів, Україна, 79000, ел. пошта oksana.palianytsia@1nu.edu.ua
}

\section{ДОСЛІДЖЕННЯ КОРОТКОПЕРІОДИЧНИХ ЗМІН СКЛАДОВИХ ЗЕНІТНОЇ ТРОПОСФЕРНОЇ ЗАТРИМКИ}

Мета цієї роботи - дослідження величини зміни складових зенітної тропосферної затримки для території України за даними кількадобових наземних метеорологічних вимірювань, а також побудова та дослідження поля їхньої зміни. Методика. Точність визначення тропосферної затримки та їі складових залежить від обсягу метеорологічних даних, які можна використати для їі розрахунку. Найкраще, якщо на момент проведення ГНСС-вимірів були б дані аерологічного зондування атмосфери, отримані поблизу пункту спостережень. В іншому разі доводиться моделювати метеорологічну ситуацію на момент проведення вимірів, використовуючи доступні для цього метеорологічні дані. У виконаних дослідженнях оцінювалося метеорологічну ситуацію в цілому для території України. Складові зенітної тропосферної затримки обчислювалася за відомою формулою Saastamoinen. За отриманими значеннями було побудовано поле зміни сухої та вологої складових зенітної тропосферної затримки для території України. Результати. Результати досліджень дають змогу проаналізувати залежність зміни величини складових тропосферної затримки від зміни метеорологічних величин на території порядку країни. У роботі отримано і проаналізовано графіки зміни складових тропосферної затримки протягом трьох діб з дискретністю 6 годин на чотирьох пунктах з різними кліматичними умовами. Встановлено, що незважаючи на суттєве розходження у значеннях складових, амплітуди їхньої зміни є близькими між собою: різниці цих амплітуд складають для сухої складової 6мм, для вологої - 2мм. Показано динаміку зміни сухої (гідростатичної) та вологої 
(негідростатичної) складових протягом двох діб. Зазначено, що їхня динаміка зумовлена зміною атмосферного тиску для сухої складової та зміною тиску водяних парів в тропосфері для вологої складової. Наукова новизна та практична значущість полягають у виявленій стабільності амплітуди зміни складових на пунктах, що знаходяться у різних кліматичних і погодних умовах. Крім цього, підтверджено, що динаміка зміни сухої складової зумовлена зміною атмосферного тиску, а вологої зміною парціального тиску. Виконані дослідження можуть використовуватися для створення регіональних моделей атмосфери та подальших досліджень поля зміни зенітної тропосферної затримки, оскільки стосуються зміни затримки в просторі і часі.

Ключові слова: тропосферна затримка; вплив тропосфери на супутникові виміри; методи визначення тропосферної затримки; визначення складових тропосферної затримки; ГНСС-виміри.

Received 04.04.2020 